\author{
Marquette University \\ e-Publications@Marquette
}

College of Communication Faculty Research and Publications

4-17-2019

\title{
Expanding Media Law and Policy Education: Confronting Power, Defining Freedom, Awakening Participation
}

Erik Ugland

Marquette University, erik.ugland@mu.edu

Follow this and additional works at: https://epublications.marquette.edu/comm_fac

Part of the Communication Commons

\section{Recommended Citation}

Ugland, Erik, "Expanding Media Law and Policy Education: Confronting Power, Defining Freedom, Awakening Participation" (2019). College of Communication Faculty Research and Publications. 529.

https://epublications.marquette.edu/comm_fac/529 


\title{
e-Publications@Marquette
}

\section{Communications Faculty Research and Publications/Diederich College of Communication}

This paper is NOT THE PUBLISHED VERSION; but the author's final, peer-reviewed manuscript. The published version may be accessed by following the link in the citation below.

Communication Law and Policy, Vol. 24, No. 2 (2019): 271-306. DOI. This article is (C) Taylor \& Francis and permission has been granted for this version to appear in e-Publications@Marquette. Taylor \& Francis does not grant permission for this article to be further copied/distributed or hosted elsewhere without the express permission from Taylor \& Francis.

\section{Expanding Media Law and Policy Education: Confronting Power, Defining Freedom, Awakening Participation}

\author{
Erik Ugland \\ Diederich College of Communication, Marquette University, Milwaukee, WI
}

\section{Abstract}

The changes brought about by the Digital Age have not triggered significant increases in political participation or meaningful reductions in longstanding social power asymmetries, which are now increasingly negotiated in policy contexts that involve mass media (surveillance, big data, net neutrality). At the same time, new technology and communication patterns have opened fissures in public opinion about the limits of free expression while also creating new legal risks for citizen-communicators. This article suggests that universities need to recalibrate their curricula to meet the exigencies of this moment, which should include an increased emphasis on media law and policy courses and initiatives. The article outlines a rationale for action, and some strategies, based on the need to: (1) expand citizens' expressive agency by equipping them with the knowledge to shield themselves from overt restraints and subtle forms of coercion; (2) deepen citizens' civics knowledge, enhance their political efficacy and enable their political participation; (3) facilitate citizens' engagement in reemerging debates about the meaning and scope of the First Amendment; and (4) spur citizen involvement in 
confronting pressing constitutional and media policy issues whose resolution will ultimately shape the broader balance of social power.

One of the early disappointments of the Digital Age is that, for all its marvels and conveniences, it has done little to expand citizens' political participation ${ }^{\underline{1}}$ or to foment significant shifts in the broader balance of social power. The democratizing effects of digital communication that many scholars and commentators had forecast $\stackrel{2}{ }$ have either not materialized or have been too pocketed to have significantly disrupted embedded social hierarchies or larger systems of political and economic control. $\underline{3}$

There are many reasons for this, not least of which is that digital communication technology is readily and effectively deployed by those already in power. More broadly, the ownership and control of new media technology and platforms, as many scholars anticipated,,$\underline{4}$ has largely been seized by big-media incumbents (Disney, Time Warner), $\frac{5}{n}$ new-media goliaths (Google, Facebook) ${ }^{6}$ and other corporations that have inordinate influence over media content, distribution, and, crucially, the policymaking process. $\underline{?}$

A related problem and a focus of this article is that too many citizens lack the key knowledge they need to mount effective challenges to the institutions that control mass media and the political leaders who drive media policy. Without understanding the mechanics of the court system and policymaking processes or the complexities of key law and policy issues, citizens are less capable of meaningfully participating in the emerging debates that are reshaping individual freedoms and social power dynamics: surveillance, big data, online privacy, media access. In the absence of this knowledge, citizens lose political efficacy - the sense that "change is possible, and that [they] can play a part in bringing [it] about"프 - reducing their likelihood of political participation and ensuring that power will further redound to those who already have it.

These knowledge deficits present more acute risks to people's individual expression. Most Americans now habitually push content into the digital ecosystem ${ }^{9}$ but without understanding all the ways in which it can trigger liability. Being able to discern these legal lines is important as a matter of self-preservation. It helps communicators avoid legal risks while fortifying them against attempts by others to censor or punish their speech, or to persuade them, through bogus information or contrived legal claims, that their speech is unprotected. Knowledge of law has a shielding effect, but it is also affirmatively empowering. If people know that their speech falls within the ambit of the First Amendment, they will be emboldened to act and will have an expanded sense of what we might call expressive agency - the ability to make autonomous choices about expression, unencumbered by law or other sources of coercion. $\underline{10}$

Few Americans are broadly knowledgeable about the law and policy aspects of mass communication. Only $57 \%$ of Americans can name freedom of speech as a right protected by the First Amendment, and just $10 \%$ can

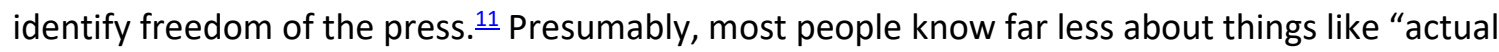
malice," $\underline{12}$ "reasonable expectations of privacy" $\underline{13}$ and "fair use." $\underline{14}$ Libel, privacy, copyright and similar subjects are certainly not addressed in secondary schools and are largely absent from post-secondary curricula as well. The only university students who typically take classes on free expression, media law or media policy are students in journalism and mass communication programs. Even law students are likely to get only glancing exposure through courses on torts and constitutional law.

These are not trivial deficiencies. Americans are in the midst of a volatile political period in which the meaning and shape of American democracy is contested and in which there is an intensifying public embrace of authoritarianism..$\underline{15}$ Free expression issues are at the center of this, in part because of the statements and actions of political leaders like Donald Trump, who regularly attacks the press $\underline{\underline{16}}$ and has threatened to scale back freespeech protections, $\underline{\underline{17}}$ and in part because of broader philosophical divisions among people about what 
constitutes speech, $\underline{\underline{18}}$ who is entitled to claim First Amendment protections, $\underline{\underline{19}}$ and who should be able to deploy and control media technology and platforms. $\underline{20}$

This article suggests that there is an urgent need to increase the public's knowledge of media law and policy, including First Amendment theory and doctrine, and that these subjects should be integrated into college and university curricula and pushed more deliberately into our communities and our political discourse. These changes could expand students' and citizens' expressive agency and political efficacy by introducing them to concepts and methods to protect their speech, and by preparing them to participate in critical public debates about media policy, the boundaries of free expression, and, more broadly, the distribution of social power. With that in mind, this article seeks to articulate a rationale for strengthening and expanding media law and policy education. It also proposes some pedagogical, curricular and programmatic initiatives that universities and other stakeholders could take to enlarge public knowledge on these subjects. $\frac{21}{1}$ These are presented at the end, not so much as solutions but as feasible steps forward; the overall focus is on providing a foundation for action, supported by relevant communication and political theory and research, and driven by the premise that it is now possible to view media law and policy courses as natural components of a contemporary liberal education. $\underline{22}^{22}$

The next section examines the contemporary context, looking at the disempowerment of citizens, particularly younger ones, and their exclusion from democratic processes, and also at the relationship between people's knowledge of law and policy and their levels of political participation. The second section looks more specifically at how this lack of knowledge and participation is playing out in the context of emerging media policy controversies and their impact on democracy and social power. The third section looks at the importance of these issues in the context of contemporary debates about the scope of the First Amendment. The fourth section looks at the connection between people's knowledge of media law and their own freedom of expression. The final section outlines proposals for expanding citizens' knowledge of media law and policy and explaining how these subjects fit in modern university curricula.

\section{Confronting Disengagement and Disempowerment}

This is a volatile and potentially perilous time for democracy around the world, with more countries turning away from the post-War American archetype of an economically liberal constitutional democracy and toward more totalitarian systems. $\underline{\underline{23}}$ This is true to some extent even in the United States, which the Economist recently downgraded from a "full democracy" to a "flawed democracy," $\underline{4}$ and which Freedom House now ranks as only the twenty-eighth most democratic country in the world. $\underline{25}$ Scholars have also documented the slow corrosion of American democracy over the past two decades, pointing to things like voter suppression, civil rights restraints, gerrymandering, lax campaign finance rules, corporate domination of policymaking and at the ways in which these things have disenfranchised or disempowered citizens. $\underline{26}$ Americans have never been less satisfied with their government. $\underline{27}$ They also are less likely to vote $\underline{28}$ or to volunteer in their communities than in the past. $\underline{29}$ These problems are more pronounced with young people who are particularly put off by politics..$\underline{30}$ Just $40 \%$ of $18-29$ year-olds in the United States voted in $2012 ; 18 \%$ did so in the off-year elections in $2014 . \frac{31}{*}$ Only

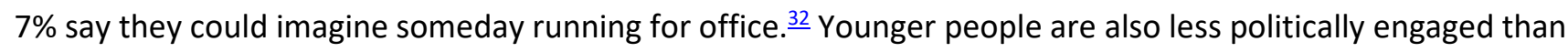
older citizens, $\underline{33}$ and they are the least avid news consumers. $\underline{34}$

This civic detachment is not unique to younger people. Americans as a whole fall short of what one might expect in a society premised on popular sovereignty and representative government. $\frac{35}{}$ Targeting younger people, however, would be the most efficient way to shift these patterns, in part because voting and non-voting political participation and inertia - are, as the research conclusively shows, self-perpetuating habits that begin to harden early in life..$^{36}$ It is essential to try to raise young people's "starting level" $\underline{37}$ of civic and political participation, which is lower today than in previous periods. $\frac{38}{}$ 
A number of foundations and educational organizations have highlighted America's "civics recession" $\underline{9}$ over the past decade and have sought to address what they perceive as a crisis in education about government $\frac{40}{-}$ by proposing steps to augment politics- and government-focused course work and activities. ${ }^{41}$ In 2012 , citing some of this work, the U.S. Department of Education issued its own report and call to action, emphasizing the need to expand civic learning and democratic engagement at all education levels. $\underline{42}$ Then Education Secretary Arne Duncan described the urgent $\frac{43}{3}$ need to "revitalize and reimagine civic education" - an argument that is supported by scholarly research on political engagement, $\underline{44}$ by the parallel research on the public's declining civic knowledge, $\underline{45}$ and by the fact that the causes of political inertia tend to compound and accelerate each other..$\underline{46}$

Contemporary political research, in aggregate, paints a portrait of American democracy in retrograde. ${ }^{47}$ Many of the democratic structures and customs that have historically kept partisan and capitalist impulses in check are being dismantled or diluted, $\stackrel{48}{=}$ and the power of the average citizen is shrinking, in part because citizens are withdrawing from traditional political and civic spheres and in part because they are getting elbowed out by more powerful interests. ${ }^{49}$ As both a cause and consequence of this, Americans are losing some of their faith in and commitment to democratic government. $\underline{50}$

Reversing these trends requires a sustained response addressing both the cognitive and behavioral aspects of the problem and targeting multiple domains, most critically higher education. Colleges and universities are where we nurture and make manifest the ideals of the Enlightenment by encouraging open debate and inquiry and by applying reason and science to complex problems. As the Supreme Court has noted, "The college classroom with its surrounding environs is peculiarly the marketplace of ideas." $\underline{15}$ It is also where, as John Dewey might note, we "educat[e] for democracy" $\underline{52}$ by providing a crucible for new ideas and giving students an opportunity to seriously examine, often for the first time, the intellectual and structural foundations of American government through courses on history, philosophy, political science, law and journalism. In addition to measurably improving students' political knowledge, motivation and efficacy, $\underline{53}$ these elements of highereducation curricula are central to what Dewey called the process of transmission whereby we convey to younger citizens both the core values and the "habits of doing, thinking, and feeling" that sustain democratic society..$\underline{54}$

Expanding students' civic knowledge yields a number of positive outcomes, all of which increase their capacity for active citizenship and their odds of becoming effective thought leaders in the future..$\underline{55}$ The opposite is also true. As the Crisis in Civic Education report notes, the public's lack of knowledge about government is not merely a deficit but "a dangerous sign of civic disempowerment." 56 It is an indicator of a citizenry that is not fully prepared for self-governance. $\frac{57}{}$ Expanding media law and policy courses and initiatives would help address these issues giving students another opportunity to study democratic government in a context that is both personally and socially salient.

Students who take semester-long, stand-alone courses on media law $\underline{58}$ learn a bit about the operation of American government, the legislative process, the application of the Constitution and its interpretation by the courts, the enforcement function of the executive branch, the relationship between state and federal law, and role of federal agencies, among other things. These are secondary foci, however, serving mostly as the scaffold for the study of issues like libel, privacy, freedom of speech, copyright, access to information, advertising regulation, and broadcast licensing. But the macro-level democratic-structure issues are illuminated through the examination of micro-level communication law issues, and in a context that is relatable to students who are already regular creators and consumers of media content. The focus on media law issues provides an accessible entry point. For some students, these courses catalyze their political interests and involvement or serve as pathways for more advanced study of subjects like political science and history. At a minimum, courses on media law and policy help to demystify the law for students, which makes their participation more likely. 
Media policy is not a major component of most media law courses, but it deserves more emphasis. Media policy focuses more on legislation and administrative law than on constitutional law and case law. It is also more attentive to social structures and processes and how power is exercised through them. It examines the intersection of politics, law and economics, with an appreciation for media history and the ways in which contemporary media phenomena are frequently enabled or set in motion by earlier policy decisions. $\underline{59}$

This is particularly useful exposure, as the next section suggests, and warrants more attention in communications curricula, including in media law courses themselves. Still, a standard media law course typically provides enough exposure to policy issues (particularly the Federal Communications Commission and Federal Trade Commission regulations) and practices to give students a foothold to be able to track policy issues and potentially engage with those processes.

\section{Rejuvenating Media Policy}

This is an unusually fluid period in American history. The rapid technologizing of society has confounded politicians who have struggled to adapt the law to meet the challenges of the moment, and it has forced judges to reexamine longstanding court precedents whose underlying presuppositions have in some cases been upended. .60 In moments like this, the law is especially vulnerable to being misdirected, which is why it is essential to get more citizens involved in the debates about media law and policy and about the scope of expressive freedom. It is particularly important to facilitate the involvement of younger citizens who, as digital natives, are especially knowledgeable and who by virtue of age have the most at stake.

Americans' media and technological dependency is self-evident. We use digital tools and platforms to execute nearly every kind of human action. Most people also recognize some of the ways in which this impacts our democracy, economy and social interactions. Some of the deeper effects, however, like the mediatization $\underline{61}$ of other facets of society, are less conspicuous, as are the below-the-surface shifts in power that occur when, for example, companies secretly capture and sell people's private data, or when foreign saboteurs "weaponize distrust" $\underline{62}$ by seeding social media sites with bogus information.

Both at the surface and at the more tectonic levels of society, mass communication practices and technologies are impacting power relationships, mostly by entrenching and enlarging the preexisting power imbalances between citizens on the one hand and government and corporations on the other. Our current media law and policy, including in some ways the prevailing libertarian interpretation of the First Amendment, $\underline{\underline{63}}$ have paved the way for this accreting concentration of power. This should be concerning but not surprising. Since World War II and particularly since the rise of Reagan-Thatcher neoliberalism - media scholars have developed a rich body of critical and political-economic research that illustrates the often anti-democratic ways in which media power is exercised and the symbiotic but not always public-interested ways in which corporate media leaders collaborate with lawmakers to achieve their goals. $\underline{64}$

For decades, scholars have emphasized the axial role of mass media in the cultivation of a vibrant public sphere and the vulnerability of media to state and corporate domination. $\underline{65}$ They warned about the amorality of marketdriven media, $\underline{6}$ about the hazards of an entirely advertising-dependent press, $\underline{67}$ and about the status-quo reinforcing effects of corporate media structures. $\underline{68}$ And, yet, the American media system is still almost entirely oriented around the twentieth century eyeballs-to-advertising model with all its attendant effects on content.

Scholars have also repeatedly warned about the consolidation of media ownership and how this would lead to more sensational, extreme, partisan and superficial content,, 99 polluting public discourse and weakening democracy. $\frac{70}{}$ Yet the media "shopping spree"1ㅡ that began with passage of the Telecommunications Act of 1996 has continued unabated. $\underline{72}$ Six media conglomerates now control nearly all of the mainstream media outlets, $\underline{73}$ and there is a resurgent deregulatory momentum ${ }^{74}$ in Washington that will likely result in further 
consolidation..$\underline{75}$ At the same time, public media are all but moribund, $\underline{76}$ and newspapers and local news outlets are dissolving, $\underline{\underline{77}}$ creating "news deserts" in many smaller communities. $\underline{\underline{78}}$ The increasingly partisan cable news networks, meanwhile, largely command the national news agenda. $\underline{79}$

Great journalistic work is being done, but the national political dialogue is dominated by media outlets that traffic in sound bites and ad hominem. This strategy is now trickling down to the local level where local broadcast stations, like those owned by Sinclair Broadcast Group, are applying the Fox News template to local TV news. $\frac{80}{}$ And there is no refuge on social media platforms, which are infected with fabrications and conspiracy theories and whose algorithms - in the case of YouTube, for example - respond to user clicks by serving up evermore incendiary content. ${ }^{81}$ It is no coincidence then that Americans are intensely polarized $\stackrel{82}{\text { and, not }}$ incidentally, that the environment in Washington, as one retiring cabinet official recently put it, is intolerably "toxic, chaotic, disrespectful and subversive."

Media scholars, since the dawn of the Digital Age, also have rejected the utopian claim that the Internet would "set us free" $\underline{\text { " }}$ and that cyberspace would be, in the words of John Perry Barlow, a "civilization of the mind" where "all may enter without privilege or prejudice" and where governments would have "no sovereignty." 15 Even "Father of the Internet" Vince Cerf assumed that the Internet would remain unbounded by geography. $\underline{\underline{86}}$ But governments have indeed penetrated and bracketed cyberspace. State censorship of the Internet and punishment of online speakers is common and increasing. .77 Freedom House reported in 2017 that

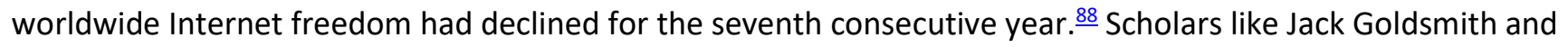
Tim Wu anticipated this, $\frac{89}{9}$ and Wu also wrote in 2010 that in the absence of deliberate, public-interested policy protections, the Internet would eventually be coopted by government and business like every other mass medium that came before it. $\underline{90}$

This is the reality in 2019. Although direct Internet censorship is not yet a problem in the United States, the government has seized control of the medium in other ways, exploiting its capacity as perhaps "the greatest spying machine the world has ever seen." 11 This pervasive state surveillance - which despite being exposed by NSA leaker Edward Snowden ${ }^{92}$ remains substantially intact - no doubt chills communication by journalists, government critics, whistleblowers and others, while also raising profound privacy questions. $\frac{93}{}$

The commercial domination of the Internet is also hard to deny. Not only is most of the popular Internet content produced by for-profit companies, media businesses (many of the same ones) also control the communications backbone that provides the public's access points. With the elimination of the net neutrality rules, $\underline{94}$ the commercial character of online media will only expand, as will the entanglements between content providers and service providers. There is, of course, still an abundance of user-generated content online, but little of this is distributed in pristine "cyberspaces" but on platforms where users must comply with the providers' rules and acquiesce to their algorithmic manipulations of content. Users typically pay another price, too, which is the surrender of their private data.

All of these issues raise important policy questions and have implications for people's individual and collective power and require the considered and collective input of engaged citizens. But there is much to repair in the lawmaking and policymaking processes as well. Citizens and citizen groups cannot match the lobbying clout of the large media companies and media industry associations. They also often lack the expertise to navigate the byzantine systems of agencies like the Federal Communications Commission and Federal Trade Commission. Those agencies, as many scholars have shown, generally favor the positions of "economic elites" $\underline{95}$ and are also susceptible to regulatory capture - the tendency of agencies, over time, to become increasingly solicitous of the companies whose industries they oversee. .96 Policy decisions tend to be made by an informal alliance among lawmakers, bureaucrats and lobbyists - the so-called Iron Triangle - who serve each other's interests. Citizen 
groups, with less to offer, are left out. The bureaucratic processes themselves, which typically include built-in mechanisms for some level of citizen involvement, are often circumscribed or subverted. $\underline{97}$

These problems are especially pronounced at the FCC whose commissioners are notorious for their close connections with industry. $\frac{98}{}$ There is a long history of revolving-door staffing at the agency where people rotate between communications companies (or the law firms representing them) to Capitol Hill to commission positions. 99 As Jeff Chester, executive director of the Center for Digital Democracy, noted in 2007, "Practically every living former [FCC] commissioner is also working for a law firm, or with some media and telecommunications company." $\underline{100}$ That trend continues today. $\underline{101}$ It would be hard to dismiss all of these problems as merely cosmetic given the agency's recent policy decisions, most notably on net neutrality. Despite the fact that $83 \%$ of Americans supported net neutrality, $\underline{102}$ including $75 \%$ of Republicans, $\underline{103}$ the FCC repealed the rules. $\frac{104}{83}$

These problems are significant and the policymaking systems are flawed, but all of it can be reoriented if citizens are engaged and knowledgeable. Universities can play a role in spreading that knowledge and equipping the next generation of leaders and policymakers to take these problems seriously, in part by refashioning their curricula to put more emphasis on these subjects (outside of communication programs), and in part by creating opportunities for students to share their knowledge and ideas on these subjects and setting a goal for them to be thought leaders, even while still in college. It is hard to overestimate all that is at stake. Decisions about government and corporate surveillance, the use of big data, the diversity and truthfulness of news sources, the control of media platforms, the security of networks, the existence of public media, and the application of new technologies (drones, sensors, ubiquitous recording devices, artificial intelligence) will determine to a great extend how society will be ordered and power distributed in the remainder of the twenty-first century. These are not peculiar and confined policy issues. They are quintessentially public issues. As Robert McChesney put it, media policy is "everybody's business." $\underline{105}$ Whatever deficiencies or imbalances exist cannot be fixed without active participation from citizens, and those habits of action need to be cultivated when they are young. $\frac{106}{}$ This is what will give individuals agency, enabling them to be drivers of media policy and not merely its subjects.

\section{Preserving and Redefining Free Expression}

In addition to grappling with all the emerging media policy issues, Americans are going to have to re-engage the debate about the meaning and scope of the First Amendment. This could be a turning-point moment for freedom of expression in America; the state of the First Amendment could become a defining social-political issue for the next generation. Whether it is a collateral effect of the public's growing antipathy toward "the media," a reaction to the proliferation of partisan news, or a reflection of a more deep-seated skepticism about free expression, people's commitment to the First Amendment is thin. Nearly a quarter of Americans say the First Amendment goes too far, $\underline{\underline{107}}$ and many seem amenable to direct suppression of certain types of content. In one recent survey, the majority of respondents supported the notion that the government should be able to fine news organizations whose reporting is biased or inaccurate, and as many approved as disapproved of the notion that courts should have the power to shut down such organizations. .108

Fake and false information is clearly one concern. $\frac{109}{}$ Another, particularly among conservatives, is speech that they view as unpatriotic or subversive (flag burning, for example), $\underline{110}$ and a third, particularly among liberals, is hate speech. $\underline{111}$ Younger people in general are less willing to protect hateful speech or offensive speech under the First Amendment than are other cohorts. $\frac{112}{}$ A Knight Foundation poll of more than 3,000 college students showed that they value free speech and diversity/inclusion more or less equally. $\underline{\underline{113}}$

According to First Amendment scholars Erwin Chemerinsky and Howard Gillman, this is an area where there is a clear generational shift. Chemerinsky and Gillman write that students in their law school courses are deeply 
sensitive to maintaining environments free of hostility and are skeptical about court precedents that affirm the right to engage in offensive speech. $\frac{114}{1}$ They write:

For [them], the historic link between free speech and the protection of dissenters and vulnerable groups is outside their direct experience, and too distant to affect their feelings about freedom of speech. As a result, their initial instinct [is] to be more trusting of the government and other public institutions, including the university, to regulate speech to protect students and prevent disruptions of the educational environment. $\frac{115}{15}$

One of the key benefits of expanding media law education would be to communicate some of this history to younger citizens. Students are understandably hesitant about extending free-speech protection to racist agitators or anti-gay provocateurs, and this might indeed be an area where First Amendment jurisprudence should be recalibrated. But those decisions should not be made without understanding the ways in which the law has been used throughout history to suppress the speech and diminish the power of others on the social periphery - abolitionists, union workers, civil rights activists, pacifists, socialists, religious minorities and atheists - in order to shield the majority from ideas it believed to be "false and fraught with evil consequence." 116 It is hard for us to imagine any truths except those that we perceive in the moment. Our censorial urges, therefore, need to be tempered by some consideration of future consequences and the long-term viability of the principle upon which we are acting. $\frac{117}{17}$ Those things are not fully recognizable without some examination of the past. $\underline{118}$

It should not be surprising that many young people, while still generally supportive of the principle of free expression, $\underline{119}$ are unmoved by some of the Supreme Court's First Amendment jurisprudence and disenchanted with some the First Amendment's real-world effects. Their lived experience is not in a world with a flourishing, Miltonian/Holmesian marketplace of ideas where people discern the truth through the careful application of science and reason. $\frac{120}{1}$ It's a cacophonous world of toxic discourse, conspiracies, and "deep fakes," $\underline{121}$ and a homophilous world where people choose their own facts. The First Amendment is not the cause of all of these problems nor necessarily their solution, but it easy to see why some might view our First Amendment jurisprudence as all Kant and no Mill $\underline{122}$ - too wedded to absolutist principles and indifferent to the facts on the ground. We have crossed the line, some might say, between righteous commitment and self-destructive fanaticism.

The real problem, in the view of some, is not so much the way the law treats citizen-speakers but the way it coddles the companies that supply media content and that control the key expressive platforms. First Amendment jurisprudence has spawned the resurgent neoliberalism in America by treating corporations as people, providing undue protection to commercial speech, and giving already dominant media enterprises a constitutional license to both consolidate ownership and ward off regulations. $\frac{123}{2}$ This permissiveness is rooted in what some say is the false assumption that the only threats to free expression that should concern us are those imposed by the state. .24

There is clearly much about America's First Amendment tradition and doctrine that is worth preserving, but also much that we should expect to be challenged. This is a time of reckoning and reassessment in which some of the most foundational questions need to be asked again and in which we encounter new questions every day: Is computer code speech? Are algorithms expressive? Are robots entitled to First Amendment protection? Is surreptitious recording constitutionally protected activity? Are Internet service providers speakers? Is native advertising commercial or editorial? $\frac{125}{}$ By expanding media law and policy education, universities can bolster people's political efficacy and enable more of them to be part of these discussions while also helping to ensure those discussions are both informed by history and attentive to contemporary realities. 


\section{Protecting the Expressive Agency of Individuals}

Individuals have agency when they have both the capability and opportunity to exercise their free will in making decisions and taking actions. Agency is essential to individual self-determination, which is the principle that

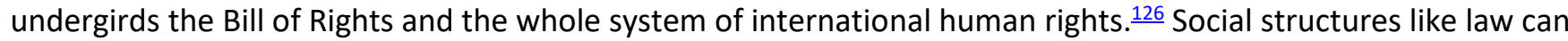
both enable and obstruct agency, and if people lack knowledge of the law, they will lack the ability to maximize their expressive opportunities and minimize impediments. Expressive agency is used here to connote the degree to which individuals are free to make autonomous decisions about what to say or publish, taking account of both the law and their knowledge about the law. .27 Knowledge of communication law and the First Amendment equips people to defend their speech from negative restraints like censorship or civil lawsuits. It also introduces them to tools like open records laws that they can use to improve the quality and impact of their speech.

The assignment of criminal and civil liability in American law is premised on the maxim that ignorance of the law excuses no one (ignorantia juris non excusat), $\underline{128}$ so there is no sanctuary for communicators who break the law even in areas like intellectual property that are unusually complicated or unsettled. This presents an extraordinary amount of new legal risk for non-professional communicators, many of whom had little reason to worry about these things a decade ago but who are now routinely capturing, producing and sharing content with mass audiences. Most of these communicators also lack education in journalism and so they are not versed in the ethical practices of the profession or its methods of verification, which tend to give traditional journalists some practical cover.

Those who acquire knowledge about media law and the First Amendment are empowered in several ways - first by being emboldened to speak at all. Expression is a constitutive act, essential to people's identity and humanness. It is how people assert themselves in the world and realize their power. It is also, at times, how they build solidarity with others. Something essential is lost to individuals and to society when people are chilled into silence. That can result from overt suppression but also from people's mere apprehension of harm. Without knowing the law people are far more likely to succumb to those apprehensions and to self-censor. Knowledge of the law can dissolve those inhibitions and give people the assurance they need to act.

Knowledge of media law and the First Amendment can help people protect themselves against acts of censorship or intimidation, which are often initiated by those who are not necessarily knowledgeable about these subjects. A university administrator, for example, might try to cut the funding of a student newspaper in a plainly unconstitutional effort to censor the publication. $\underline{129}$ Or police officers might violate the rights of citizen bystanders by confiscating their smart phones after being recorded while making an arrest. $\frac{130}{3}$ Both of these actions would violate the rights of the speakers, but if these speakers were not familiar with the law, they might, respectively, acquiesce to the funding cuts or defer to the authority of the police officers. So, not only would they lack the knowledge to defend themselves, their cognizance of their own ignorance would lead them to assume the other party, as the initiator of the action, held the stronger position. A lack of knowledge, then, can create an artificial power differential even in situations where neither party is more informed than the other.

Of course, sometimes there is an actual power differential between the speaker and the person seeking to suppress speech. When the knowledgeable party knows the speaker is less knowledgeable, there is a high risk of abuse and manipulation. The most common example is where a powerful person, through his or her lawyer, threatens a lawsuit or sends a cease and desist letter. Such a missive is rarely an actual step toward litigation but are nevertheless chilling to a less knowledgeable speaker.

Large, corporate copyright owners are regular perpetrators of these kinds of exploitations. The major studios and record labels relentlessly file takedown notices with YouTube and other social media sites to shut down uses of their content. $\frac{131}{1}$ They often do this without considering whether the use is a fair use, because they recognize that many less-knowledgeable users will simply comply in order to avoid the risk. $\frac{132}{}$ When thousands or millions 
of users do this it creates a culture of compliance. The copyright owners are therefore able wield their knowledge in ways that change outcomes without changing the law.

Creating an apprehension of liability is a tactic that has worked for other copyright owners as well. One of the most important elements of the fair use defense is the effect of the use on the market for the original work. $\frac{133}{3}$ By using similar intimidation tactics and inducing users to be in the habit of paying to use copyrighted works, the copyright owners are able to say in subsequent cases that any unauthorized uses necessarily impact their market because normally people pay. By bullying current users into paying for the work, they help create a "permissions culture" $\underline{134}$ while also building a factual foundation to defeat fair use claims by future users. $\underline{135}$

The most obvious way in which knowledge of media law and the First Amendment can empower people is by allowing them to simply stay out of legal trouble. People using social media, for example, who do not know anything about the law of libel or privacy, are likely to be either bounded by their ignorance - by self-censoring in response to the uncertainty or buckling to the claims of would-be plaintiffs - or will forge ahead blindly, putting themselves in legal jeopardy.

When people lack knowledge about the law, their tendency is to take cues from others and conform their behavior to the practices of those around them. This can often provide some protection in the sense that people are normally compliant with the law and so aligning one's behavior with the customs of the majority usually keeps one in proximity of legality. As Rudolf Leonhard wrote more than a century ago, "Human customs everywhere fit themselves to the law. As a rule, whoever follows these customs may be sure of not offending the law even if he ignores the statutes and the other local forms of law." $\underline{136}$ This is only half true, of course. There are many customs and habits that have emerged in the Digital Age of mass communication that do not align with the law (illegal file-sharing, for example). In the absence of actual legal knowledge, the new wave of amateur communicators either mimic the practices of the community or rely on word-of-mouth legal advice. The Digital Age has spawned a whole body of ersatz law based on hand-me-down urban myths: You can't be sued for a re-tweet; public officials can't sue for libel; you can use up to four seconds of a copyrighted song without permission; false speech, hate speech and commercial speech are not protected by the First Amendment. People who rely on this crowd-sourced legal knowledge either put themselves in legal jeopardy or limit the possibilities of their own expression.

Expanding people's knowledge of media law and the First Amendment is about more than self-preservation and avoiding liability for social media posts. It is essential for restoring some equilibrium in the distribution of power across society by ensuring that citizen-communicators can serve as effective watchdogs of the people and institutions with the greatest social influence. Despite the democratization of access to communication technology, there are still extraordinary power disparities in society. People need to actively assert and fight for their sovereignty or it will simply be taken. It is essential, then, that this new generation of citizencommunicators be able to effectively use the law to exercise their own power while also checking its exercise by law enforcement officials, politicians, business leaders and others. People need to know when they can record in public, what government records they can access, what spaces they can occupy, and what meetings they can attend. All of this will enable their public-focused communication while expanding their expressive agency and their resilience in the face of intimidation. $\underline{137}$

\section{Steps Forward: Expanding Education on Media Law and Policy}

In 1970, renowned speech communication professor Franklyn Haiman was asked to explain to his colleagues why he studied and wrote about free speech and, more specifically, why he thought it should be taught in speech communication programs. He noted that for decades "press law" courses had been common in journalism programs. He wrote, "Certainly the oral communicator, whether his medium be the public speech or 
rally, radio or television, stage or screen, needs equally to know his rights and responsibilities." $\underline{138}$ Indeed, it is worth asking half a century later why, in a time of ubiquitous communication, all citizens should not acquire at least some of that same knowledge. Of course, what people need is more than a basic understanding of their rights and responsibilities, as Haiman surely would agree. But even some rudimentary knowledge is enough to help people activate their own expression and shield themselves from interference while also facilitating their broader civic engagement.

This article assumes that the strength of a democracy can be gauged in part by the extent to which its citizens participate through their votes, their political expression and their collective action. $\frac{139}{}$ This participation does not always occur naturally and is often actively discouraged or obstructed, at times by the government itself, so it has to be taught and practiced. In addition to helping students acquire the knowledge they need to engage in debates about media law and policy, faculty teaching these courses should create opportunities to cultivate these habits of participation by getting students to apply their knowledge through direct action and to publicly share their ideas.

There is no single act or initiative that could address all of the problems identified above, and some of these will be more applicable to, or feasible for, some than others. They are not exotic and that is intentional. The goal here is simply to identify some priorities and realistic next steps that align with established or emerging best practices in pedagogy and that are attentive to some of the broader goals for twenty-first century higher education identified by groups like the American Association of Colleges and Universities. AACU proposes that institutions of higher education must help preserve a just society by developing a new generation of "intentional learners" who actively participate as citizens in a diverse democracy. ${ }^{140}$ In pursuit of that goal it urges faculty to, among other things, emphasize problem-based and team-based learning, create off-campus learning experiences, develop service-learning programs and develop courses that force students to address current social problems and propose solutions. $\frac{141}{}$ Faculty teaching law and policy are well situated not only to impart useful knowledge to students (including those outside of communication programs) that can help those students preserve their expressive agency, but also to create opportunities that help students prepare for lives of active citizenship.

\section{Preserving Coursework Within Communication}

Before embarking on any new curricular initiative, journalism and mass communication programs $\frac{142}{14}$ should first preserve and build on what they already offer. Courses on media law have long been part of standard journalism and mass communication curricula and remain part of the tradition. The very first core competency mentioned in the standards of the Accrediting Council on Education in Journalism and Mass Communication emphasizes the need for students to "understand and apply the principles and laws of freedom of speech and press ..., receive instruction in and understand the range of systems of freedom of expression around the world, including the right to dissent, to monitor and criticize power, and to assemble and petition for redress of grievances." $\underline{143}$

That is a heavy load, and not a realistic educational goal for programs that do not have a stand-alone course in media law that is required of students in the major. It is too much to expect these subjects to get adequate coverage if they are only addressed incidentally in courses on reporting, editing, management, and similar topics. It is also not possible for programs to satisfy the ACEJMC standard if they merge their media law course with media ethics - something many programs do in order to create curricular efficiencies, often so they can respond to the growing demand for skills and production courses. Other programs might simply combine law and ethics because they view them as complementary subjects, which they are. The problem is that there is not enough time in these combined courses to give both subjects the attention they deserve. $\frac{144}{1}$ 
A required media law course should be the minimum standard offering in all journalism and mass communication programs. Departments with sufficient resources should also consider offering a separate, elective course on media policy. Some programs already go much further, offering courses on the political economy of mass media, or special seminars on Internet law, telecommunications policy, intellectual property and other subjects. And some collaborate with programs in political science, law or business. Only a few programs have the capacity to provide this much curricular depth, but a media law course requirement is certainly a reasonable and feasible expectation.

\section{Expanding Coursework Outside of Communication}

America's journalism and mass communication programs have for decades been the primary academic institutions committed to teaching students about media law and the only academic bodies that have consistently sought to educate undergraduate students about the history and meaning of the First Amendment. Faculty in these programs have led generations of students in examining the role of free expression in society and have prepared those students to understand and drive public debates about these issues. The students taking these courses, however, have been almost exclusively undergraduate juniors and seniors in communication programs. It is rare for students outside these programs to have significant exposure to these issues in their undergraduate curricula, even though freedom of speech and press are core cultural and constitutional values, and even though much of today's human interaction and civic engagement occurs in mediated or other online platforms. Nearly every citizen is now at least occasionally a public communicator, and many citizens perform journalistic functions by gathering and sharing information of public significance. But instead of treating media law and policy as foundational subjects for equipping people to securely and meaningfully engage in public life, these classes have remained sequestered within communication departments.

A simple first step would be to open media law and policy courses to non-majors, as some programs do. A better approach would be to develop a new course specifically tailored to the general university population. This would not be difficult. Even though it is sometimes helpful for students taking media law courses to have already completed other courses in the communication curriculum, it is not essential. For most communication majors, the media law course is their first significant exposure to the subject, so there is no reason to think that noncommunication majors would face any insurmountable problems.

A refashioned course for non-communication majors might address the subject from a slightly different vantage point, with more emphasis on individual communicators than institutional ones. It could explore subjects like newsgathering and access but with an emphasis on citizen journalism, and it might look at commercial speech regulation more from the perspective of the consumer. It might also put more emphasis on some nonjournalistic contexts like public expression and protest; free speech in the workplace; social media policy and platforms' terms of use; and campaign finance law and the First Amendment.

The course could cover most of the same subjects as the standard course but with some small modifications. It would certainly need to address the foundational topics that are relevant to all communicators, such as prior restraint, libel and privacy, among others. It might be useful, however, to scrape away some of the more technical details and to put more emphasis on history, theories and rationales so that students are better prepared to critically evaluate the law and explore opportunities for reform.

Some of this winnowing could be done in each of the principal units of the course. In libel, for example, one could eliminate some of the material on jurisdictional issues, types of damage awards, and some of the details of the various defenses without major sacrifice. In the privacy area, the appropriation and right of publicity material, while important, could be scaled back. In the newsgathering area, some of the reporter's privilege and 
free press-fair trial material might be less relevant to non-journalists. Much of the advertising and commercial speech content could be compressed. And while it would still be important to address many of the FCC's rules for broadcast, cable and internet communicators, some of the more arcane ones could just be mentioned briefly or bypassed. $\underline{145}$ There are also some whole subject areas that could be wholly or nearly eliminated. Obscenity law, for example, is fascinating but has largely fallen off the radar of courts and legislatures. The standard unit on open records and meetings could also be abridged. It is crucial that these issues still be addressed, but it is probably enough for most students to know about the existence of these laws and their general scope without diving too deeply into the case-law interpretations. Making some of these changes would create space to examine some of the other expressive contexts noted earlier and to more fully address key policy issues like net neutrality, surveillance and big data, among other possibilities. $\underline{.46}$

None of this is to suggest that a course aimed at non-communication students should be less rigorous or conceptual than a traditional course. Indeed, its tighter focus would ideally make it easier for faculty to build in more theoretical and historical components. The ultimate goal would be for students to begin formulating and articulating their own theories about the balance between freedom and restraint so that they can be intelligent contributors to public debates about media law and policy. That is not possible without some practice in deconstructing the law, scrutinizing the rationales that support it and examining the political and procedural structures that shape it.

\section{Externalizing Media Law and Policy: Practicums and Advocacy}

One of the first things media law students discover is that the law is less the embodiment of timeless doctrines than the product of an ongoing social and political negotiation. There are few fixed principles in American law and little consensus among judges about the meaning of legal texts or about the interpretive methods judges should apply to them. It is important that students recognize this dynamism, because they often have creative ideas for reforming the law and they have the potential to be thought leaders on these subjects. Unfortunately, their voices are largely absent from the public conversations about free expression and media policy.

Faculty teaching media law courses could help inform and energize those debates, as some do, by not only encouraging their students to challenge the received wisdom about media law and policy, but also requiring them to disseminate their ideas off campus. This can involve basic assignments like writing opinion pieces, columns, blog posts, letters to the editor, or producing and posting videos or podcasts. More advanced students could also work on drafting amicus briefs in active court cases, perhaps in collaboration with law students or faculty. For media policy courses in particular, adding an advocacy component like this could be particularly fruitful and those courses could serve as known and recurring sources of new ideas on media reform.

There are even more direct ways in which media law students could apply their knowledge beyond the classroom. They could propose or lobby for legislation, submit public comments or speak in open forums. Students might be more likely to do this if they are also among the parties affected. Several states have recently passed or considered laws dealing with cyberbullying, online privacy, social media password protection, and student free expression, and have given students the opportunity to offer live testimony to legislative committees. Faculty cannot always count on opportunities like this arising, but by creating a themed seminar that is regularly offered, they can adapt it to whatever issues are salient that semester.

Faculty might only find that one or two of these ideas for externalizing the class experience are realistic in a given semester but implementing any of them would help advance the larger goal of graduating new cohorts of students who are both knowledgeable for their own sake and also experienced and habituated contributors to public debates. ${ }^{147}$ Any of these activities would be a step toward preparing students for what the American Council on Education calls "engaged citizenship," 148 and what the Department of Education calls "democratic 
engagement," 149 which requires "educational experiences that intentionally prepare students for informed, engaged participation in civic and democratic life by providing opportunities to develop civic knowledge, skills, and dispositions through learning and practice." ${ }^{150}$ There are many ways that faculty can help students achieve those ends, but the emphasis should be on external application because the research clearly demonstrates the long-term educational benefits of those activities. $\underline{151}$

\section{Peer Education and Service Learning: Workshops and Forums}

Another way to elevate public knowledge on media law and policy issues is through forums, workshops, lectures or panels that are aimed at non-experts. Students and faculty can work together to conduct these sessions as a way of educating the broader university community about these issues and stimulating debate. The impact could be magnified if these sessions were able to reach the broader public as well, either by inviting the community to come to campus, or by taking these programs to other sites within the community. These sessions would need to be tightly focused sessions designed to teach people about a specific media law subject (the elements of libel, the basics of fair use, for example) or to provide an informational overview of a more complicated subject (net neutrality, for example) as way of empowering people to weigh in on the broader public policy debate.

There is considerable scholarly research showing positive educational benefits from peer teaching and peer learning, $\frac{152}{2}$ so these activities could simultaneously expand public knowledge and foster student learning. Students could easily take these educational sessions to public high schools or community centers or find other ways for them to have more of a service-learning dimension as well.

\section{Summer Institutes and Certificate Programs}

Universities around the country are looking for ways to use summer to accelerate students' degree progress and generate more revenue by attracting students from other universities or the community and taking advantage of otherwise unused resources. A multi-credit summer institute focused on media law and policy, perhaps combined with media ethics, could give students a chance to acquire special expertise in these subjects and could introduce non-communication students and others unaffiliated with the university, particularly citizen journalists or others with communication-focused careers and interests (public policy, government, non-profits), providing an opportunity to develop some specialized knowledge while also earning a university certificate or similar credential.

\section{Conclusion}

The most immediate aim of this article was to suggest that in this new era, when virtually every American citizen is a mass communicator, there is a pressing need to expand citizens' knowledge of media law, policy and the First Amendment, and that universities can play an important role in meeting that challenge. Enhancing citizens' knowledge of these subjects enlarges their expressive agency by helping them to avoid legal risks and to defend themselves against direct and indirect suppression. It also apprises them of tools and resources they can use to enhance the quality and impact of their speech and, potentially, to play a role in holding those in power accountable.

At the same time, public opinion about the First Amendment and free expression is especially fluid right now. People are intensely divided about the breadth of expressive freedom and about some of the assumptions underlying much of the Supreme Court's First Amendment jurisprudence. Technological changes are also forcing us to reconsider conventional answers to elemental questions like what is speech, and who is a speaker. Universities need to do their part to help ensure that these debates about the meaning of the First Amendment are as informed as possible and that they are attentive to history but not chained to it. 
Expanding citizens' base of knowledge on these media-related subjects will also be important in the broader political sphere. Many of the most powerful companies in the world are media companies,,$\frac{153}{}$ and many of the world's richest individuals made their fortunes in the media sector. ${ }_{154}$ And some of the most urgent policy questions of this era, which will substantially determine the balance of social power in the next century, involve the media in one way or another: government and corporate surveillance, net neutrality, hacking, big data, the Internet, artificial intelligence, algorithmic communication. The country needs as many knowledgeable citizens as possible to make their voices heard on these issues.

For democracy to work, there has to be an equilibrium between the practical power of citizens, on the one hand, and government and business on the other. They will never be equal in every respect, but we should worry when there are gross imbalances, as there are now. $\underline{155}$ We should also worry when citizens, in the face of these inequities, start to disengage politically. With that in mind, the proposals at the end of this article focused not just on the inculcation of knowledge but on finding ways for students to apply that knowledge to affect political and social change and to give them opportunities to envision themselves as the thought leaders and change agents of the next generation.

\section{Notes}

1 See, e.g., Politics and Web 2.0: The Participation Gap npn [Preface] (Gisela Goncalves \& J. Paulo Serra eds., 2016) (describing the "paradox between the seemingly limitless promise modern Web technologies hold for enhanced political communication and their limited actual contribution," and noting that "empirical evidence indicates that neither citizens nor political parties are taking full advantage of online platforms to advance political participation."); Shelley Boulianne, Does Internet Use Affect Engagement? A Meta-Analysis of Research, 26 Pol. Comm. 193 (2009) (showing, through a meta-analysis of research on this subject, an overall negative effect of Internet use on civic and political engagement).

2 See, e.g., Yochai Benkler, The Wealth of Networks (2006); Tom Friedman, The Lexus and the Olive Tree (1998); George Gilder, Telecosm: The World After Bandwidth Abundance (2002); Nicholas Negroponte, Being Digital (1995); Clay Shirky, Here Comes Everybody (2008).

3 See generally Matthew Hindman, The Myth of Digital Democracy (2008); Jon Katz, Virtuous Reality (1997); Robert W. McChesney, Digital Disconnect: How Capitalism is Turning the Internet Against Democracy (2012).

4 See Robert W. McChesney, Rich Media, Poor Democracy 119 (1999).

5 The American media marketplace is now dominated by six major conglomerates: Disney, Time Warner, Comcast, National Amusements (parent of Viacom and CBS), News Corp, and Sony. They are collectively worth half a trillion dollars. See Media Conglomerates: The Big

6, WebpageFX.com, https://www.webpagefx.com/data/the-6-companies-that-own-almost-allmedia/ (last visited Oct. 7, 2018) (citing data from the Securities and Exchange Commission, the Columbia Journalism Review and from the companies themselves). AT\&T is in the process of acquiring Time Warner - an $\$ 85$ billion deal that was recently approved by a federal judge. See Hadas Gold \& Brian Stetler, Judge Approves \$85 Billion AT\&T-Time Warner Deal, CNN.com, Jun. 13, 2018, http://money.cnn.com/2018/06/12/media/att-time-warner-ruling/index.html.

6 Google/Alphabet, Amazon and Facebook together have market values of more than \$1 trillion. See Market Capitalization of the Largest U.S. Internet Companies as of March 2016, Statistica, http://www.statista.com/statistics/209331/largest-us-internet-companies-by-marketcap/ (last visited Oct. 7, 2018). Facebook and Google account for $73 \%$ of all digital advertising and control 83\% of all online ad growth. See Jillian D'Onfro, Google and Facebook Extend Their Lead in Online Ads, and That's Reason for Investors to be Cautious, CNBC.Com, Dec. 20, 
2017, https://www.cnbc.com/2017/12/20/google-facebook-digital-ad-marketshare-growthpivotal.html.

7 In 2018, Alphabet/Google, AT\&T, Comcast, Amazon and Facebook, along with the National Association of Broadcasters and the NCTA Internet \& Television Association, were all among the top twenty lobbying clients in the country. See Top Spenders, Open

Secrets, https://www.opensecrets.org/lobby/top.php?showYear=2016\&indexType=s (last visited Oct. 27, 2018).

8 Agnus Campbell, Gerald Gurin \& Warren E. Miller, The Voter Decides 187 (1954).

9 Almost $90 \%$ of Americans use the Internet. See Monica Anderson, Andrew Perrin \& Jinjing Jiang, 11\% of Americans Don't Use the Internet. Who Are They?, Pew Research Center, Mar. 5, 2018, http://www.pewresearch.org/fact-tank/2018/03/05/some-americans-dont-use-the-internet-whoare-they/. Nearly $70 \%$ of Americans use social media. David Cohen, $86 \%$ of U.S. Adults Aged 18-29 Are Social Media Users: Report, Adweek, Jan. 12, 2017, http://www.adweek.com/digital/pew-researchcenter-fact-tank-january-2017/.

10 "Agency" is a broad concept with a variety of meanings in different disciplines and contexts, but in social research it typically refers to the capacity of individuals to exercise free will in making intentional choices about their own lives. See Mustafa Emirbayer \& Ann Mische, What is Agency?, $103 \mathrm{Am}$. J. of Soc. 962, 965 (1998) (describing one version of agency as "the capacity of human beings to shape the circumstances in which they live"); Marcus H. Kristiansen, Agency as an Empirical Concept: An Assessment of Theory and Operationalization (Netherlands Interdisciplinary Demographic Institute, Working Paper, June 2014). The term "expressive agency" is used here as an indicator of the extent to which people's expressive decisions are impeded by formal law, their own knowledge or ignorance of the law, and by other social norms or expectations.

11 Newseum Institute, State of the First Amendment 20152 (2015).

12 This is the fault standard that public officials must satisfy when bringing civil suits for defamation. See New York Times v. Sullivan, 376 U.S. 254, 279-80 (1964) (a public official must prove "that the statement was made with 'actual malice' - that is, with knowledge that it was false or with reckless disregard of whether it was false or not."). This requirement was extended to defamation suits by public figures in Curtis Pub. Co. v. Butts, 388 U.S. 130 (1967).

13 Plaintiffs bringing intrusion-based privacy suits typically must prove that the defendant intruded into a space in which the plaintiff had a "reasonable expectation of privacy." See, e.g., Wilkins v. NBC, 71 Cal. App. 4th 1066, 1073 (1999). A similar standard, using the same basic phrasing, is applied by courts in Fourth Amendment search and seizure cases. See United States v. Katz, 389 U.S. 347, 361 (1967) (Harlan, J., concurring) (" $[A]$ person [must] have exhibited an actual (subjective) expectation of privacy and, second, that expectation [must] be one that society is prepared to recognize as 'reasonable.'").

14 This is the statutory exception to the general rule under the U.S. Copyright Law that copyright owners retain complete control over the use of their works. 17 U.S.C. $\$ 107$ (2015).

15 See Matthew C. MacWilliams, The Rise of Trump: America's Authoritarian Spring (2016).

16 In addition to his many public statements on this topic, President Donald Trump's Twitter feed is replete with criticisms of journalists and media organizations. See, e.g., Donald J. Trump

(@realDonaldTrump), Twitter (Feb. 17, 2017, 3:48

p.m.), https://twitter.com/realDonaldTrump/status/832708293516632065 ("The FAKE NEWS media (failing@nytimes, @CNN, @NBCNews and many more) is not my enemy, it is the enemy of the American people. SICK!").

17 While still a candidate, Trump proposed changing libel laws to make it easier for people to sue the media. See Adam Liptak, Can Trump Change Libel Laws?, N.Y. Times, Mar. 30, 2017, available at https://www.nytimes.com/2017/03/30/us/politics/can-trump-change-libel-laws.html? $r=0$ (“I'm 
going to open up our libel laws so when they write purposely negative and horrible and false articles, we can sue them and win lots of money,' Mr. Trump said.").

18 The most conspicuous example of this is the continuing controversy over the Supreme Court's decision in Citizens United v. FEC, 558 U.S. 310 (2010), in which the Court held, in part, that corporations, not merely individuals, have a First Amendment right to fund communications about political candidates.

19 Courts still disagree, for example, about who is eligible to claim protections under the First Amendment reporter's privilege and under state shield laws, all of which give some protection to reporters to refuse to comply with certain subpoenas seeking their work products or testimony. See Erik Ugland \& Jennifer Henderson, Who is a Journalist and Why Does it Matter? Disentangling the Legal and Ethical Arguments, 22 J. of Mass Media Ethics 241 (2007).

20 One example of this is the debate over net neutrality. During the Obama Administration, the FCC imposed a series of rules limiting the extent to which Internet service providers could block, channel or prioritize Internet traffic. Protecting and Promoting the Open Internet, 47 C.F.R. §8 (2017). In late 2017, with Republican commissioners in the majority, the FCC repealed the rules. Restoring Internet Freedom, 83 Fed. Reg. 7852 (Feb. 22, 2018) (to be codified at 47 C.F.R. pts. 1, 20, 8).

21 These proposals are distinct from the broader effort to expand students' media literacy or news literacy. Those projects are principally aimed at developing students' capacity to process, critique and contextualize media messages. Some initiatives also emphasize a media production competency as well. The National Leadership Conference on Media Literacy defined media literacy as the "ability of a citizen to access, analyze, and produce information for specific outcomes." Patricia Aufderheide, Media Literacy: A Report of the National Leadership Conference v (1992). Media literacy units are more common at the $\mathrm{K}-12$ level and there is still a need to integrate more of this material into university curricula where the overall media literacy project remains in "its infancy stages." Hans Schmidt, Media Literacy Education at the University Level, 12 J. of Effective Teaching 64, 70 (2012). Media literacy education is most broadly implemented at the university level through course offerings like "Media in Society" and "Media and Culture," which are often available to non-communication majors, and through more advanced courses that introduce students to critical analytical methods or perspectives. Some of the more general courses will typically touch on aspects of media law and policy, but these, while useful as introductions, are not sufficient to obviate the need for the kinds of things proposed in this article. To the extent that programs offer courses on media history or the political economy of mass media, those are certainly mutually reinforcing of courses on law and policy, but are still one step removed, and they are not typically taken by, or available to, non-communication majors. At the broadest level, media literacy education and media law and policy education share a common objective to prepare students to be savvy and engaged citizens. Media literacy can help students "wield power, make rational decisions, become effective change-agents, and have an effective involvement with the media." Len Masterman, Teaching the Media 13 (1985). But law and policy tend to be tertiary points of emphasis in media literacy education and so the latter should not be viewed as a substitute for the former.

22 To be sure, there are many subjects that will warrant heightened attention from universities in the coming years as universities adapt their curricula to meet the exigencies of this moment. This article merely suggests that media law and policy should be among them, not that they are the only ones worth elevating.

23 See, e.g., Freedom House, Freedom in the World 20174 (2017) (documenting a global shift away from democracy and toward populism and autocracy and noting that "[a]fter years of major gains, the share of Free countries has declined over the past decade while the share of Not Free countries has risen."). 24 Economist Intelligence Unit, Democracy Index 2016 (2016), http://www.eiu.com/topic/democracy-index. 25 Freedom House, supra note 23, at 18. The United States is ranked sixteenth in the Global Democracy Index, http://democracyranking.org/wordpress/ (last visited Oct. 7, 2018). GDI is based on a series of 
weighted indicators derived from other sources: Freedom House political rights index (25\%), Freedom House civil liberties and political rights index (25\%), World Economic Forum Gender Gap Report (25\%), Freedom House press freedom index (10\%), Transparency International corruption perceptions index (10\%), peaceful change of leadership (2.5\%), and peaceful political party change of head of government (2.5\%). These data are only current through 2016 and therefore do not consider changes that have occurred since the start of the Trump Administration.

26 See, e.g., Martin Gilens \& Benjamin I. Page, Testing Theories of American Democracy, 12 Persp. on Politics 564 (2014) (arguing that the United States is no longer a majority-rules society in the sense that the policy preferences of the wealthy are much more likely to be enacted than those preferred by less wealthy citizens).

27 See, e.g., Public Trust in Government 1958-2014, Pew Research Center, Nov. 13, 2014, http://www.peoplepress.org/2014/11/13/public-trust-in-government/. See also Public Trust in Government Remains Near Historic Lows as Partisan Attitudes Shift, Pew Research Center, May 3, 2017, http://www.peoplepress.org/2017/05/03/public-trust-in-government-remains-near-historic-lows-as-partisan-attitudesshift/.

28 See Michael P. McDonald, Voter Turnout Demographics, United States Elections Project, http://www.electproject.org/home/voter-turnout/demographics (last visited Oct. 7, 2018).

29 See Andy Kiersz, Volunteering in America is at its Lowest Level in Over a Decade, Bus. Insider, Feb. 25, 2016, http://www.businessinsider.com/bls-volunteering-chart-2016-2 (citing Bureau of Labor Statistics Data showing a steady decline in volunteerism beginning in 2003).

30 See With Rare Exceptions, America's Young are Turning Their Backs on Politics, The Economist, May 16, 2015, at 30 (citing Jennifer Lawless \& Richard Fox, Running From Office: Why Young Americans Are Turned Off To Politics (2015)).

31 See McDonald, supra note 28.

32 See With Rare Exceptions, supra note 30, at 30.

33 See Ellen Quintelier, Differences in Political Participation Between Young and Old People, 13 Contemp. Pol. 165, 165 (2007). Of course, most citizens, particularly younger ones, are engaging in more online political activity. See Aaron Smith, Civic Engagement in the Digital Age, Pew Research Center, Apr. 25, 2015, http://www.pewinternet.org/2013/04/25/civic-engagement-in-the-digital-age/. But they also complain that these platforms are often rancorous and unproductive outlets for political expression. See Maeve Duggan \& Aaron Smith, The Political Environment on Social Media, Pew Research Center, Oct. 25, 2016, http://www.pewinternet.org/2016/10/25/the-political-environment-on-socialmedia/. Some scholars also suggest that social media political communication is taking the place of other more meaningful forms of political participation, Boulianne, supra note 1, and that it encourages "slacktivism" - online communication that give people a sense that they are weighing in and contributing but without really changing real-world outcomes. Henrik Serup Christensen, Political Activities on the Internet: Slacktivism or Political Participation by Other Means?, First Monday, Feb. 7, 2011, http://firstmonday.org/ojs/index.php/fm/article/view/3336/2767\&quot;\&gt;.

34 See Carlos Lozada, Why We May Never Have a Millennial President, Wash. Post, May 20, 2015, available at https://www.washingtonpost.com/news/book-party/wp/2015/05/20/why-we-may-never-have-amillennial-president/?utm term=.5a67963cc394. Millennials spend just over half as much time with news sources as do people 65 and over. Id.

35 Fewer than $58 \%$ of eligible U.S. voters participated in the 2016 elections, and of the thirty-five countries in the Organization for Economic Cooperation and Development, the United States ranks twenty-eighth in voter turnout. See Drew Desilver, U.S. Trails Most Developed Counties in Voter Turnout, Pew Research Center, May 15, 2017, http://www.pewresearch.org/fact-tank/2017/05/15/u-s-voter-turnout-trailsmost-developed-countries/. 
36 See, e.g., Daniel A. McFarland \& Reuben J. Thomas, Bowling Young: How Youth Voluntary Associations Influence Adult Political Participation, 71 Am. Soc. Rev. 401, 401-02 (2006) ("For most citizens, the process of becoming politically active (or inactive) begins in early adulthood when people initially become eligible to vote, join political parties, and engage in adult civic organizations. Thereafter, political participation becomes a habituated behavior."). See also Eric Plutzer, Becoming a Habitual Voter: Inertial, Resources, and Growth in Young Adulthood, 96 Am. Pol. Sci. Rev. 41, 41 (2002).

37 Plutzer, supra note 36 , at 41.

38 Constance Flanagan \& Peter Levine, Civic Engagement and the Transition to Adulthood, 20 The Future of Children 159, 160 (2010).

39 National Task Force on Civic Learning and Democratic Engagement, A Crucible Moment: College Learning and Democracy's Future 7 (2012) (quoting Charles N. Quigley, executive director of the Center for Civic Education).

40 See American Council of Trustees and Alumni, A Crisis in Civic Education (2016).

41 See sources cited at supra notes 39-40. See also Campaign for the Civic Mission of Schools, Guardian of Democracy: The Civic Mission of Schools (2011); Campus Compact, A Promising Connection: Increasing College Access and Success Through Civic Engagement (2010); Anne Colby, Elizabeth Beaumont, Thomas Ehrlich \& Josh Corngold, Educating for Democracy: Preparing Undergraduates for Responsible Political Engagement (2007); Education Testing Service, Fault Lines in our Democracy: Civic Knowledge, Voting Behavior and Civic Engagement in the United States (2012).

42 U.S. Dept. of Educ., Advancing Civic Learning and Engagement in Democracy: A Road Map and Call to Action 3 (2012). The report was co-produced by the Department of Education, the National Task Force on Civic Learning and Democratic Engagement, the American Commonwealth Partnership, and the Campaign for the Civic Mission of Schools.

43 ld. at v.

44 See Politics and Web 2.0, supra note 1.

45 See, e.g., Colby et al., supra note 41, at 3; State of the First Amendment, supra note 11; Americans' Knowledge of the Branches of Government Is Declining, Annenberg Public Policy Center (Sep. 13, 2016), http://www.annenbergpublicpolicycenter.org/americans-knowledge-of-the-branches-ofgovernment-is-declining/.

46 For example, without sufficient political knowledge, people are less likely to engage in political activity, which further limits their opportunities to acquire new knowledge. Similarly, without sufficient financial resources, people are less likely to be politically active, which further limits their opportunities to influence policy in ways that could improve their economic standing. See American Political Science Association, American Democracy in an Age of Rising Inequality 5-6 (2004). See also Norman H. Nie, Jane Junn \& Kenneth Stehlik-Barry, Education and Democratic Citizenship in America 31 (1996) (referring to the connection between social class and political participation as perhaps the "best-documented finding in American political behavior research.").

47 See generally Amanda Taub, How Stable are Democracies? "Warning Signs are Flashing Red," N.Y. Times, Nov. 29, 2016, available at https://www.nytimes.com/2016/11/29/world/americas/westernliberal-democracy.html? $r=0$.

48 There are many examples but the most conspicuous is the enhanced power of corporations to influence the political process as a result of the Supreme Court's decision in Citizens United v. F.E.C., 558 U.S. 310 (2010) (holding that the First Amendment prevents the government from limiting corporations' spending in support of political candidates).

49 See, e.g., Gilens \& Page, supra note 26, at 565.

50 See Roberto Stefan \& Yascha Mounk, The Danger of Deconsolidation: The Democratic Backslide, 27 J. of Dem. 5,7 (2016) ("Citizens in a number of supposedly consolidated democracies in North America and 
Western Europe ... have also become more cynical about the value of democracy as a political system, less hopeful that anything they do might influence public policy, and more willing to express support for authoritarian alternatives.") .

51 Healy v. James, 408 U.S. 169, 180 (1972) (quoting Keyishian v. Board of Regents, 385 U.S. 589, 603 (1967)). 52 Colby et al., supra note 41.

53 ld. at 5.

54 John Dewey, Democracy and Education 9 (1916).

55 See William A. Galston, Civic Education and Political Participation, 25 Phil. \& Pub. Pol'y Q. 18, 21 (2005) (outlining a number of benefits flowing from increased civic knowledge, including the promotion of democratic values, the increase in political participation, the greater ability of citizens to defend their own interests, the expansion of citizens' capacity to acquire new knowledge about civic affairs, and the enlargement of public trust that flows from the demystification of government processes, among other things); Eric Plutzer, Becoming a Habitual Voter: Inertia, Resources, and Growth in Young Adulthood, 96 Am. Pol. Sci. Rev. 41, 53 (2002) (emphasizing the connection between political knowledge and voting).

56 American Council, supra note 40, at 6.

57 True self-governance with a fully engaged and broadly knowledgeable citizenry has always been the aim of American democracy. See 9 The Writings of James Madison 103 (Gaillard Hunt ed., 1910) (Letter to W.T. Barry, Aug 4, 1822) ("A popular government without popular information is but a prologue to a tragedy, or a farce; or, perhaps both. Knowledge will forever govern ignorance: And a people who mean to be their own governors must arm themselves with the power which knowledge gives.").

58 Some programs combine media law with media ethics. It should also be noted that not every program uses the term "media law" to describe its course on this subject. Some use Communications Law, Media Law and Regulation, Law of Public Communication, Communication Law and Policy, or something similar. The use of the term "media law" in this article should be read as a reference to all of these types of courses, most of which address the same core material, even if there are some slight variations from one version of the course to the other.

59 See Des Freedman, The Politics of Media Policy 10-15 (2008) (outlining some traditional definitions and conceptions of media policy).

60 Many of the Supreme Court's key decisions outlining the First Amendment status of various mass media were issued decades ago under different media conditions. See, e.g., Reno v. ACLU, 521 U.S. 844, 867 (1997) (distinguishing the Internet from broadcasting based on the now dubious notion that, unlike broadcasting, getting access to Internet content requires users to make a "series of affirmative steps" to access material); Turner Broadcasting Sys., Inc. v. F.C.C., 512 U.S. 622 (1994) (upholding certain cable television regulations based on the monopolistic market conditions of the time, which are no longer so pronounced); Red Lion Broadcasting Co. v. F.C.C., 395 U.S. 367 (1969) (upholding regulation of broadcast content at a time when most viewers had access to only a handful of broadcast stations).

61 "Mediatization" is a theoretical framework addressing the ways in which media influence the norms, logics and vocabularies of other disciplines like education and politics. See generally Stig Hjarvard, The Mediatization of Culture \& Society (2013); Andreas Hepp, Stig Hjarvard \& Knut Lundby, Mediatization: Theorizing the Interplay between Media, Culture and Society, 37 Culture \& Soc'y 314 (2015).

62 Sen. Ben Sasse: Stop Weaponizing Distrust, CNN.com, Mar. 26, 2018 ("There's an important to distinction to draw between bad stories and crappy coverage ... and trying to weaponize distrust."), https://www.cnn.com/videos/politics/2017/07/02/ben-sasse-trump-weaponize-distrustmedia-sot-sotu.cnn. 
63 See, e.g., Amanda Shanor \& Robert Post, Adam Smith's First Amendment, 128 Harv. L. Rev. F. 165 (Mar. 16, 2015); Morgan N. Weiland, Expanding the Periphery and Threatening the Core: The Ascendent Libertarian Speech Tradition, 69 Stan. L. Rev. 1389 (2017).

64 There is more work than can be effectively summarized here but some of the key scholars in the earlier periods included the Frankfurt School scholars Herbert Marcuse, Theodor Adorno, Max Horkheimer, Walter Benjamin and Jürgen Habermas; American scholars such as Herbert Schiller and Dallas Smythe, and British scholars Peter Golding and James Curran. Later work by Vincent Mosco, Janet Wasco, Oscar Gandy, Noam Chomsky, Neil Postman, Ben Bagdikian, Robert McChesney, C. Edwin Baker and Jerome Barron added to this scholarly lineage. Many of those scholars are still producing excellent work and are joined by some successors, including Victor Picard, Philip Napoli, Tim Wu, Laura Stein, Manuel Puppis and hundreds of others around the world. For a thorough review of the history of this field of research, see Robert W. McChesney, Communication Revolution: Critical Junctures and the Future of Media 37-98 (2007).

65 See Jürgen Habermas, The Structural Transformation of the Public Sphere: An Inquiry into a Category of Bourgeois Society (1991).

66 See David Croteau \& William Hoynes, The Business of Media: Corporate Media and the Public Interest 24 (2d ed. 2006) (arguing that most mass media represent the "market model" in that they are commercially focused, and that they are generally amoral - though not necessarily immoral - in the sense that they are not driven by a public-directed sense of obligation beyond attracting the largest audiences and the most revenue).

67 See, e.g., C. Edwin Baker, Advertising and a Democratic Press (1994).

68 See, e.g., Edward S. Herman \& Noam Chomsky, Manufacturing Consent: The Political Economy of the Mass Media (1988).

69 See, e.g., McChesney, supra note 4.

70 See, e.g., C. Edwin Baker, Media Concentration and Democracy: Why Ownership Matters (2007); C. Edwin Baker, Media, Markets and Democracy (2002).

71 Jeff Chester, Digital Destiny: Media and the Future of Democracy 21 (2007).

72 See Stephen Grocer, A Record \$2.5 Trillion in Mergers Were Announced in the First Half of 2018, N.Y.Times.com, July 3, 2018, https://www.nytimes.com/2018/07/03/business/dealbook/mergersrecord-levels.html (noting that most of these mergers were in media and health care); Peter Vernon, Mergers, Acquisitions and the New Media Landscape, Colum. J. Rev., July 20, 2018, available at https://www.cjr.org/the media today/att-time-warner-disney-fox-comcast.php.

73 See supra note 5.

74 The FCC recently issued a notice of proposed rulemaking to eliminate some of the rules regarding media ownership, including the newspaper/broadcast cross-ownership rule and the radio/television crossownership rule. FCC, Notice of Proposed Rulemaking, MB Docket No. 17-289 (2017). One FCC commissioner also has called for the elimination of the children's programming rules. See Michael O'Rielly, It's Time to Reexamine the FCC's Kid Vid Requirements, FCC.gov, Jan. 26, 2018, https://www.fcc.gov/news-events/blog/2018/01/26/its-time-reexamine-fccs-kid-vidrequirements.

75 Indeed, a federal judge gave AT\&T permission to acquire Time Warner, see supra note 5, and Sinclair Broadcasting is seeking to acquire Tribune Media Co., although the deal is on hold for now after the FCC rejected the initial proposal.

76 These outlets attract a only small percentage of the total audience, and their survival is now dependent on viewer/listener contributions and corporate and foundation gifts. The government's contribution to public media has been dwindling for decades, and in his most recent budget proposal, President Donald Trump called for the complete elimination of funding for public media. See Brian Stelter, PBS Denounces 
Trump's Proposed Funding Cuts (Again), CNN.com, Feb. 12,

2018, http://money.cnn.com/2018/02/12/media/public-media-funding-2019-budget/index.html.

77 See Local Journalism: The Decline of Newspapers and the Rise of Digital Media (Rasmus Kleis Nielsen ed., 2015); Derek Thompson, The Print Apocalypse and How to Survive It, The Atlantic, Nov. 3, 2016, available at https://www.theatlantic.com/business/archive/2016/11/the-print-apocalypse-andhow-to-survive-it/506429/.

78 "News deserts" are created when local news organizations (usually newspapers) collapse, leaving smaller towns without viable sources of unbiased local news. See Tom Sittes, New Data Tracks How Fast News Deserts are Spreading, Poynter.org, Jun. 1, 2018, https://www.poynter.org/news/new-data-tracks-howfast-news-deserts-are-spreading.

79 During the 2016 presidential election year, for example, the three most popular sources of election news among voters were Fox News, CNN and Facebook. See Jeffrey Gottfried, Michael Barthel \& Amy Mitchell, Trump, Clinton Voters Divided in Their Main Source of Election News, Pew Research Center, Jan. 18, 2017, http://www.journalism.org/2017/01/18/trump-clinton-voters-divided-in-their-main-sourcefor-election-news/.

80 See Sydney Ember, Sinclair Requires TV Stations to Air Segments That Tilt to the Right, N.Y.Times.com, May 12, 2017, https://www.nytimes.com/2017/05/12/business/media/sinclair-broadcast-komoconservative-media.html; How Sinclair Broadcasting Puts a Partisan Tilt on Trusted Local News, PBS News Hour, Oct. 10, 2017, https://www.pbs.org/newshour/show/sinclair-broadcasting-puts-partisantilt-trusted-local-news.

81 See Zeynep Tufekci, We're Building a Dystopia Just to Make People Click on Ads, Ted.com, Sept. 2017, https://www.ted.com/talks/zeynep tufekci we re building a dystopia just to make people cl ick on ads\#t-140169.

82 See Carroll Doherty, Key Takeaways on Americans' Growing Partisan Divide Over Political Values, Pew Research Center, Oct. 5, 2017, http://www.pewresearch.org/fact-tank/2017/10/05/takeaways-onamericans-growing-partisan-divide-over-political-values/ (showing that the partisan division between democrats and republicans is twice as large as it was just 20 years ago).

83 David J. Shulkin, Opinion: Privatizing the V.A. Will Hurt Veterans, N.Y. Times, Mar. 28, 2018, available at https://www.nytimes.com/2018/03/28/opinion/shulkin-veterans-affairs-privatization.html.

84 McChesney, supra note 4, at 119.

85 John Perry Barlow, A Declaration of the Independence of Cyberspace (Feb. 8, 1996), available at EFF.org, https://www.eff.org/cyberspace-independence.

86 See Jack Goldsmith \& Tim Wu, Who Controls the Internet? Illusions of a Borderless World 58 (2006).

87 See Rebecca MacKinnon, Consent of the Networked: The Worldwide Struggle for Internet Freedom (2012); Joel Simon, The New Censorship: Inside the Battle for Media Freedom (2015).

88 Freedom House, Freedom on the Net 2017 (2017), https://freedomhouse.org/report/freedom-net/freedomnet-2017.

89 See Goldsmith \& Wu, supra note 86, at 65-85.

90 Tim Wu, The Master Switch: The Rise and Fall of Information Empires 256 (2010).

91 Patrick Kingsley, Julian Assange Tells Students that the Web is the Greatest Spying Machine Ever, The Guardian, Mar. 15, 2011, https://www.theguardian.com/media/2011/mar/15/web-spying-machinejulian-assange.

92 See Glenn Greenwald, No Place to Hide: Edward Snowden, The NSA, and The U.S. Surveillance State (2014).

93 See Human Rights Watch and American Civil Liberties Union, With Liberty to Monitor All: How Large-Scale U.S. Surveillance is Harming Journalism, Law and American Democracy (2014).

94 See supra note 20. 
95 See Gilens \& Page, supra note 26, at 565 (showing that the policy preferences of "economic elites" and "business interest groups" are significantly more likely to be enacted than those of either "average citizens" or "mass-based interest groups").

96 See generally Ernesto Dal Bó, Regulatory Capture: A Review, 22 Econ. Pol'y 203 (2006).

97 See Deserai A. Crow, Elizabeth A. Albright \& Elizabeth Koebele, Public Information and Regulatory Processes: What the Public Knows and Regulators Decide, 33 Rev. of Pol'y Res. 1 (2016).

98 See Pat Aufderheide, Communications Policy and the Public Interest: The Telecommunications Act of 1996 (1999) (describing the involvement of lobbyists in the drafting of the Telecommunications Act of 1996); Jeff Chester, Digital Destiny: Media and the Future of Democracy 59-61 (2007) (describing the regular intermingling of FCC commissioners and lobbyists).

99 See, e.g., Robbie Feinberg, The Comcast-FCC Revolving Door, OpenSecrets.org, Apr. 18 2014, https://www.opensecrets.org/news/2014/04/the-comcast-fcc-revolving-door/.

100 Chester, supra note 98 , at 58.

101 There are many examples but the most obvious is that the current FCC chair, Ajit Pai, had only worked as a communications lawyer or as congressional staffer before becoming FCC Commissioner and then head of the agency.

102 See Harper Neidig, Poll: 83 Percent of Voters Support Keeping FCC's Net Neutrality Rules, TheHill.com, Dec. 12, 2017, http://thehill.com/policy/technology/364528-poll-83-percent-of-voters-support-keeping-fccsnet-neutrality-rules.

103 See id.

104 See supra note 20.

105 See McChesney, supra note 64, at 4.

106 This notion was expressed well by former United Nations General Secretary Kofi Anan, who said, "No one is born a good citizen; no nation is born a democracy. Rather, both are processes that continue to evolve over a lifetime." Press Release, United Nations, A Society That Cuts Itself Off From Its Youth Severs Its Lifeline (Aug. 10, 1998).

107 Newseum Institute, State of the First Amendment 20172 (2017).

108 Attitudes Towards the Mainstream Media Take an Unconstitutional Turn, The Economist, Aug. 2, 2017, available at https://www.economist.com/blogs/graphicdetail/2017/08/daily-chart-0.

109 This is serious concern among all groups. Seventy-four percent do not think fake news should be protected by the First Amendment. Newseum Institute, supra note 107, at 5.

110 See Conor Friedersdorf, America's Many Divides Over Free Speech, The Atlantic, Oct. 9, 2017, available at https://www.theatlantic.com/politics/archive/2017/10/a-sneak-peek-at-new-survey-data-on-freespeech/542028/ (citing results of a 2017 YouGov poll) ("Republicans were most intolerant of speech and most likely to favor authoritarian laws to punish it on the subject of burning or desecrating the American flag: Seventy-two percent of Republicans believe that should be illegal (along with 46 percent of Democrats.").

111 ld. ("Yet a majority of Americans ... believe that 'society can prohibit hate speech and still protect free speech.'”).

112 See Jacob Poushter, 40\% of Millennials OK with Limiting Speech Offensive to Minorities, Pew Research Center, Nov. 20, 2015, http://www.pewresearch.org/fact-tank/2015/11/20/40-of-millennials-ok-withlimiting-speech-offensive-to-minorities/.

113 Free Expression on Campus: What College Students Think About First Amendment Issues, Knight Foundation, Mar. 11, 2018, https://www.knightfoundation.org/reports/free-expression-on-campuswhat-college-students-think-about-first-amendment-issues.

114 Erwin Chemerinsky \& Howard Gillman, What Students Think About Free Speech, Chon. of Higher Ed., Apr. 3, 2016, available at https://www.chronicle.com/article/What-Students-Think-About-Free/235897. 
115 Id.

116 Whitney v. California, 274 U.S. 357, 374 (1927) (Brandeis, J., concurring).

117 So, when the president attacks "the media" (a nondescript term that invites people to imagine their own favored targets) and proposes changing the libel laws to make it easier for people to sue, it is harder for people to see the downside if they are not familiar with some of this history. See Hadas Gold, Donald Trump: We're Going to "Open Up" Libel Laws, Politico, Feb. 26, 2016, available at https://www.politico.com/blogs/on-media/2016/02/donald-trump-libel-laws-219866 ("We're going to open up libel laws, and we're going to have people sue you [the media] like you've never got sued before.").

118 The fake news issue provides another example. Before we indulge the impulses of the majority to fine or shut down fake news Web sites, we need to consider all the ways in which that power could be abused. The advertisement at issue in New York Times Co. v. Sullivan, after all, was filled with inaccuracies and could have been characterized, on some level, as "fake news." New York Times Co. v. Sullivan, 376 U.S. 254, 258 (1964) ("It is uncontroverted that some of the statements contained in the two paragraphs were not accurate descriptions of events which occurred in Montgomery.").

119 See Jeffrey Adam Sachs, The "Campus Free Speech Crisis" is a Myth: Here are the Facts, Wash. Post, Mar. 16, 2018, available at https://www.washingtonpost.com/news/monkey-cage/wp/2018/03/16/the-campusfree-speech-crisis-is-a-myth-here-are-the-facts/?utm term=.f3593641f6ca (citing data from the General Social Survey showing broad tolerance among young people for offensive speech).

120 See Abrams v. United States 250 U.S. 616, 630 (Holmes, J., dissenting) ("[T]he ultimate good desired is better reached by free trade in ideas - that the best test of truth is the power of the thought to get itself accepted in the competition of the market); John Milton, Areopagitica: A Speech for the Liberty of Unlicensed Printing, in The Oxford Authors: John Milton 236, 269 (Stephen Orgel \& Jonathan Goldberg eds., Oxford Univ. Press 1990) (1644) ("And though all the windes of doctrin were let loose to play upon the earth, so Truth be in the field, we do injuriously, by licencing and prohibiting to misdoubt her strength. Let her and Falshood grapple; who ever knew Truth put to the wors, in a free and open encounter.").

121 The term "deep fake" was initially used to describe pornographic, explicit or embarrassing videos in which the face of one of the subjects was replaced, using digital technology, by the face of a celebrity. The term is now used by some to describe the more general use of video manipulations designed to fool people. See, e.g., Drew Harwell, Fake-Porn Videos Are Being Weaponized to Harass and Humiliate Women: "Everbody is a Potential target," Wash. Post, Dec. 30, 2018, available at https://www.washingtonpost.com/technology/2018/12/30/fake-porn-videos-are-being-weaponizedharass-humiliate-women-everybody-is-potential-target/?utm term=.b31f011e3947; Hilke Schellmann, Deepfake Videos Are Getting Real and That's the Problem, Wall Street J., Oct. 15, 2018, available at https://www.wsj.com/articles/deepfake-videos-are-ruining-lives-is-democracy-next1539595787

122 Analogizing from the field of moral philosophy, one might say that First Amendment law is too deontological (rules-based) and oriented around absolute principles akin to Immanuel Kant's categorical imperative. See Kant's Moral Philosophy, Stanford Encyclopedia of Philosophy (last updated July 7, 2016), https://plato.stanford.edu/entries/kant-moral/\#CatHyplmp ("[A]ct only in accordance with that maxim through which you can at the same time will that it become a universal law."). This contrasts with the more teleological (consequence-based) approach of John Stuart Mill's utilitarianism. See The History of Utilitarianism, Stanford Encyclopedia of Philosophy (last updated Sept. 22, 2014), https://plato.stanford.edu/entries/utilitarianism-history/ (emphasizing that the morally right action is the one that produces the greatest good for the greatest number). 
123 See, e.g., Blurring the Lines: Market-Driven and Democracy-Driven Freedom of Expression (Eva-Maria Svensson, Andrew T. Kenyon \& Maria Edström eds., 2016); Freedom of Expression and Media in Transition: Studies and Reflections in the Digital Age (Ulla Carlsson ed., 2016); Tamara R. Piety, Brandishing the First Amendment (2012); Tamara R. Piety, The Heroic Corporation and First Amendment Romanticism: A Response to Professors Redish and Neuborne, 92 Tex. L. Rev. 182 (2014).

124 See, e.g., Laura Stein, Speech Rights in America: The First Amendment, Democracy, and the Media (2006); Andrew Calabrese \& Colleen Mihal, Liberal Fictions: The Public Private Dichotomy in Media Policy, The Handbook of Political Economy of Communication 226 (Janet Wasco, Graham Murdock \& Helena Sousa eds., 2011).

$125 \mathrm{~A}$ form of sponsored content, native advertising is "any paid advertising that takes the specific form and appearance of editorial content from the publisher itself." Bartosz W. Wojdynski \& Nathaniel J. Evans, Going Native: Effects of Disclosure Position and Language on the Recognition and Evaluation of Online Native Advertising, 45 J. of Advertising 157, 157 (2016).

126 See Art. 1(3) of both the International Covenant on Civil and Political Rights (1966) and the International Covenant on Economic, Social and Cultural Rights (1966). See also Robert McCorquodale, SelfDetermination: A Human Rights Approach, 43 Int'I Comp. L. Q. 857 (1994).

127 There are many other factors that could affect people's expressive agency - everything from media platforms' terms of use, to the influence of advertisers, to less concrete things like people's perceived duties to employers, friends or family - but the focus here is on both law and knowledge of law.

128 See Frederick G. McKean Jr., The Presumption of Legal Knowledge, 12 St. Louis L. Rev. 96, 96 (1927). Although a defendant's knowledge of the law is always presumed, that is different than whether he or she acted willfully or intentionally in situations in which the tort or crime requires scienter. Ignorance of the law should also be distinguished from the inability to comprehend the law. Laws that are insufficiently clear about what is permitted or prohibited can be struck down for vagueness under the Due Process Clause of the Fourteenth Amendment or the due process component of the Fifth Amendment. See Gentile v. State Bar of Nevada, 501 U.S. 1030 (1991).

129 Funding denials as retribution for objections to content are a violation of the First Amendment. See Rosenberger v. Univ. of Virginia, 515 U.S. 819 (1995).

130 There is a growing body of precedent from the federal courts upholding the First Amendment right of citizens to record police officers while they are on the job. See Fields v. Philadelphia, 862 F.3d 353 (3d Cir. 2017).

131 The Digital Millennium Copyright Act, 17 U.S.C. $§ 512$ (2018), establishes a process allowing owners of copyrighted works to file takedown notices with Web sites and social media platforms when they believe someone is using their copyrighted work illegally. Users can then file counter-notifications to keep the content online, at least in the absence of a filed lawsuit. This process also creates a safe harbor allowing the websites to avoid liability for any violations by users, provided they comply with the noticeand-takedown protocol.

132 There is little disincentive for the companies. The DMCA imposes a good faith obligation on the part of the requester to not abuse the notice and takedown process, but violations only occur when there are "knowing" and "material" misrepresentations. 17 U.S.C. §512(f) (2018). The worst that is likely to happen in most cases is that the user files a counter-notification and the content remains online. The copyright owners know from experience, however, that most users will not even go that far. The Ninth Circuit put a speed bump in place to try to mitigate some of these exploitations of the law when it ruled that before filing take-down notifications, copyright owners must first consider whether use of their content is a fair use. Lenz v. Universal Music Corp., 801 F.3d 1126 (9th Cir. 2015).

133 See supra note 14. 
134 Patricia Aufderheide, Peter Jaszi, Bryan Bello \& Tijana Milosevic, Copyright, Permissions, and Fair Use Among Visual Artists and the Academic and Museum Visual Arts Communities, Report to the College Art Association 5 (2014).

135 An even more devious strategy among some copyright owners is the honeypot approach where the copyright owners deliberately circulate their copyrighted works online (for example, photos of celebrities) expecting that people will discover and use the content without permission. The owners then sue or threaten to sue the users and induce a settlement. See, e.g., Sofia M. Fernandez \& Eriq Gardner, Katy Perry Photos at Center of \$3 Millon Paparazzi Showdown, The Hollywood Reporter, Dec. 6, 2011, https://www.hollywoodreporter.com/thr-esq/katy-perry-photo-lawsuit-mavrix-270145.

136 Rudolf Leonhard, The Vocation of America for the Science of Roman Law, 26 Harv. L. Rev. 389, 407 (1913). 137 In addition to enlarging the expressive agency of individuals, spreading this knowledge can expand the collective agency of communicators by making people more sensitive to each other's freedoms and challenges. The more educated people are about free expression and the history of the First Amendment, the more likely they will be to come to the defense of their fellow citizen-communicators, including those in other countries. This is particularly important now given the rise of global censorship and acts of violence against journalists. See The Assault on Journalism: Building Knowledge to Protect Freedom of Expression (Ulla Carlsson \& Reeta Pöyhtäri eds., 2017).

138 Franklyn S. Haiman, Why Teach Freedom of Speech?, 9 Free Speech Yearbook 1, 2 (1970).

139 See I Alexis de Toqueville, Democracy in America 299 (Vintage Classics. The Henry Reeve Text as revised by Francis Brown 1990) (1835) (noting that civic participation in the town centers was the key to limiting the despotism of the majority and "impart[ing] to the people a taste for freedom and the art of being free.").

140 Association of American Colleges and Universities, Greater Expectations: A New Vision for Learning as the Nation Goes to College 33 (2002).

141 ld.

142 To be sure, programs in speech communication or communication studies also occasionally offer courses that address some of these issues. Those courses should absolutely be preserved in the curriculum. They do tend to have a slightly different focus, however, with more emphasis on demonstrations, protest, assembly, political speech, art, rhetoric, social movements, and similar topics, and less emphasis on mass or mediated communication.

143 Accrediting Council on Education in Journalism and Mass Communication, Principles of Accreditation: Professional Values and Competencies, http://www.acejmc.org/policies-process/principles/ (last visited Oct. 8, 2018).

144 This should not be understood as any kind of indictment of law and ethics as a combined course or to rebut those who support blending these subjects. Some of the top scholars and teachers in the field teach law and ethics together with great success. The point is simply that separating them would create opportunities for more depth of study and some pedagogical flexibility to incorporate some of the activities mentioned later in this section.

145 Some of these might include spectrum allocation/policy, licensing requirements, the equal time and equal opportunity rules, the must-carry, leased-access, PEG and franchising rules for cable, among others.

146 With some further adjustments, it would be possible to create a law-policy hybrid course that more intentionally blends these subjects, putting slightly less emphasis on black-letter law and more focus on critical analysis and media reform.

147 Research and task force reports frequently emphasize the importance of engaging in debates. See, e.g., Colby et al., supra note 41, at 5 (noting key educational strategies for democratic engagement, including "(1) political discussion and deliberation; (2) political action and research projects; (3) invited speakers who represent political engagement of various sorts or aspects of policy 
formulation and implementation; (4) internships or placements in government agencies, non-profits and other organizations dealing with political and policy issues; and (5) structured reflection on readings, placements, political action or other experiences"); A Crucible Moment, supra note 39, at 3 ("Moreover, full civic literacies cannot be garnered only by studying books; democratic knowledge and capabilities also are honed through hands-on, face-to-face, active engagement in the midst of differing perspectives about how to address common problems that affect the well being of the nation and the world.").

148 Colby et al., supra note 41, at 3 (quoting an uncited report from the American Council on Education).

149 U.S. Dept of Educ., supra note 42, at 1. ("By civic learning and democratic engagement we mean educational experiences that intentionally prepare students for informed, engaged participation in civic and democratic life by providing opportunities to develop civic knowledge, skills, and dispositions through learning and practice.").

150 ld.

151 See, e.g., Campus Compact, A Promising Connection: Increasing College Access and Success Through Civic Engagement 1 (2010) ("Research demonstrates that connecting the classroom to the community is an effective pedagogical strategy. College students who participate in civic engagement learning activities not only earn higher grade point averages but also have higher retention rates and are more likely to complete their college degree. They also demonstrate improved academic content knowledge, critical thinking skills, written and verbal communication, and leadership skills. Moreover, these students show increased interest in becoming personally and professionally involved in future community enhancement projects."). See also lasonas Lamprianou, Contemporary Political Participation Research: A Critical Assessment, in Democracy in Transition 37 (Kyriakos N. Demetriou ed., 2013) (emphasizing that those who become politically engaged tend to continue those practices in the future to be consistent with themselves and avoid creating dissonance in their values).

152 See Daniel A. McFarland \& Reuben J. Thomas, Bowling Young: How Youth Voluntary Associations Influence Adult Political Participation, 71 Am. Soc. Rev. 401, 401 (2006) (noting that "speaking in public forums and generating a communal identity most encourage future political participation"). See also Keith J. Topping, Trends in Peer Learning, 25 Educ. Psy. 631 (2005).

153 Apple, Amazon, Facebook, Tencent, Alibaba, Charter, Alphabet/Google and Comcast are all among the top twenty richest companies in the world based on market capitalization. See Here are the 20 Largest Companies in the World by Market Cap, Business Tech, July 12, 2017, https://businesstech.co.za/news/business/184817/here-are-the-20-largest-companies-in-theworld-by-market-cap/.

154 Mark Zuckerberg (Facebook), Michael Bloomberg (Bloomberg Media), Sergey Brin (Google), Larry Page (Alphabet), Jeff Bezos (Amazon/Washington Post), Bill Gates (Microsoft), and Carlos Slim (formerly the largest New York Times shareholder) are all among the richest people in the world. See Richest People in the World, CBS News, https://www.cbsnews.com/pictures/richest-people-in-world-forbes/21/ (last visited Nov. 3, 2018).

155 See generally The New Gilded Age: The New Critical Inequality Debates of Our Time (David Grusky ed., 2012). 